\title{
FLT1 Gene
}

National Cancer Institute

\section{Source}

National Cancer Institute. FLT1 Gene. NCI Thesaurus. Code C18414.

This gene is involved in cellular proliferation, differentiation and tyrosine kinase signal transduction. 